\title{
Sensitive Spectrophotometric Determination of Atenolol in Pharmaceutical Formulations Using Bromate-Bromide Mixture as an Eco-Friendly Brominating Agent
}

\author{
Kudige N. Prashanth and Kanakapura Basavaiah \\ Department of Chemistry, University of Mysore, Manasagangotri, Mysore 570006, Karnataka, India \\ Correspondence should be addressed to Kanakapura Basavaiah, basavaiahk@yahoo.co.in
}

Received 25 November 2011; Accepted 27 December 2011

Academic Editor: Dario Compagnone

Copyright ( $) 2012$ K. N. Prashanth and K. Basavaiah. This is an open access article distributed under the Creative Commons Attribution License, which permits unrestricted use, distribution, and reproduction in any medium, provided the original work is properly cited.

\begin{abstract}
Three simple and sensitive spectrophotometric methods are proposed for the determination of atenolol (ATN) in bulk drug and tablets. The methods are based on the bromination of ATN by the bromine generated in situ by the action of the acid on the bromate-bromide mixture followed by the determination of unreacted bromine by reacting with a fixed amount of either metacresol purple (MCP) and measuring the absorbance at $540 \mathrm{~nm}$ (method A) and $445 \mathrm{~nm}$ (method B) or erioglaucine (EGC) and measuring the absorbance at $630 \mathrm{~nm}$ (method C). Beer's law is valid within the concentration ranges of 1.0-20.0, 2.0-40.0 and 1.0$8.0 \mu \mathrm{g} / \mathrm{mL}$ for method A, method B and method C, respectively. The calculated molar absorptivities were found to be $1.20 \times 10^{4}$, $4.51 \times 10^{3}$ and $3.46 \times 10^{4} \mathrm{~L} / \mathrm{mol} \cdot \mathrm{cm}$ for method A, method B and method C, respectively. Sandell's sensitivity values, correlation coefficients, limits of detection and quantification are also reported. Recovery results were statistically compared with those of a reference method by applying Student's $t$ - and F-test. The novelty of the present study is the measurement of two different colors using MCP, that is, red-pink color of MCP in acid medium at $540 \mathrm{~nm}$ and yellowish-orange color of brominated MCP at $445 \mathrm{~nm}$.
\end{abstract}

\section{Introduction}

Atenolol (ATN), chemically known as 4-(2-hydroxy-3-[(1methylethyl) amino] propoxy) benzeneacetamide [1], is a $\beta 1$-selective (cardio selective) adrenoreceptor antagonist drug used for antiangina treatment to relieve symptoms, improve tolerance, and as an antiarrhythmic to help regulate heartbeat and infections. It is also used in management of alcohol withdrawal, in anxiety states, migraine prophylaxis, hyperthyroidism, and tremors [2]. The drug is official in Indian Pharmacopoeia [3] which describes a UV-spectrophotometric method and also in British Pharmacopoeia [4] which recommends high-performance liquid chromatographic (HPLC) method for its determination. Several methods have been reported for the determination of ATN in pharmaceutical dosage forms and include diffuse reflectance spectroscopy [5], HPLC [6-26], high-performance thin-layer chromatographic (HPTLC) [27, 28], ultra performance liquid chromatography (UPLC) [29], gas chromatography (GC)
[30, 31], nonsuppressed ion chromatography [32], flourometry $[33,34]$, differential scanning calorimetry (DSC) and thermogravimetry (TG) [35], electrophoresis, [36-38] voltammetry [39], ion-selective electrode- (ISE-) based potentiometry [40], atomic absorption spectrometry (AAS) [41], UV-spectrophotometry [42-50], visible spectrophotometry [51-62], and titrimetry [60-62].

To the best of our knowledge, there are twelve reports on the use of visible spectrophotometry for the determination of ATN in pharmaceutical formulations. Agrawal et al. [51] have reported a method based on the reaction of ATN with hydroxylamine hydrochloride in $\mathrm{NaOH}$ medium followed by the reaction of the resultant hydroxamic acid derivative with $\mathrm{FeCl}_{3}$ to give a red-violet ferric hydroxamate complex. Assays based on charge transfer complexation reaction of ATN with chloranilic acid have been reported by Agarwal et al. [52] and Yu et al. [53]. Korany et al. [54] have developed a method based on the treatment of a $\mathrm{CHCl}_{3}$ extract of powdered tablets of atenolol with acetaldehyde, a 
halogenated benzoquinone reagent (chloranil, 2,5-dichlorobenzoquinone, or 2,6-dibromobenzoquinone chlorimine), and propan-2-ol. The slow reaction between ATN and ammonium vanadate in sulphuric acid medium resulted in two kinetic spectrophotometric methods (fixed-concentration method and fixed-time method) [55]. Al-Ghannam and Belal [56] used the reaction between ATN and 4-chloro7-nitrobenzo-2-oxa-1,3-diazole in borate buffer of $\mathrm{pH} 8$ at the boiling temperature for the kinetic spectrophotometric assay of drug. The method developed by Hiremath et al. [57] is based on the oxidation of atenolol by a known excess of permanganate in alkaline media and determination of unreacted permanganate spectrophotometrically at $526 \mathrm{~nm}$. Bashir et al. [58] have reported a method based on determination of ATN in basic medium, followed by addition of sodium nitroprusside to generate a coloured complex. Basavaiah et al. [59] have reported a method based on the oxidation of ATN by a measured excess of chloramine- $\mathrm{T}$ followed by determination of the unreacted oxidant by a charge-transfer complexation reaction involving metol and sulphanilic acid. The assay method based on the oxidation of ATN by a known excess of chloramine- $\mathrm{T}$ in acid medium followed by determination of the unreacted oxidant by reacting with a fixed amount of either metanil yellow or indigo carmine have been reported by Basavaiah et al. [60]. A similar method [61] employed bromate-bromide mixture, methyl orange as reagents in acid medium. An acid-base reaction employing phenol red has also been reported by the same authors [62]. However, many of the above methods suffered from one or other disadvantage like poor sensitivity, heating or extraction step, use of organic solvents, use of expensive chemical, and/or complicated experimental setup as can be seen from Table 1.

The aim of this study was to develop three new spectrophotometric methods for the assay of ATN based on bromination of ATN by a green brominating agent (i.e., bromine-generated in situ). The methods use bromated-bromide mixture, metacresol purple (MCP), and erioglaucine (EGC) as reagents. The proposed methods are economical compared to the previously reported chromatographic techniques. Moreover, these methods are sensitive, simple, does not involve heating or extraction step, and free from usage of hazardous chemicals. Since inexpensive and easily available chemicals are used, the developed methods evidence low cost per analysis.

\section{Experimental}

2.1. Apparatus. All absorbance measurements were made on a Systronics model 106 digital spectrophotometer (Systronics, Ahmadabad, India) provided with $1 \mathrm{~cm}$ matched quartz cells.

2.2. Materials and Reagents. All chemicals and reagents used were of analytical or pharmaceutical grade. Distilled water was used to prepare the solutions.
(1) Bromate-Bromide Mixture (40, 80, and $18 \mu \mathrm{g} / \mathrm{mL})$. A stock standard bromate-bromide mixture solution equivalent to $500 \mu \mathrm{g} / \mathrm{mL} \mathrm{KBrO}_{3}$ was prepared by dissolving accurately weighed $50 \mathrm{mg}$ of $\mathrm{KBrO}_{3}$ (S. D. Fine Chem. Ltd., Mumbai, India) and $0.5 \mathrm{~g}$ of $\mathrm{KBr}$ (Merck, Mumbai, India) in water and diluted to the mark in a $100 \mathrm{~mL}$ calibrated flask. The stock solution was diluted appropriately with water to get the working concentrations of 40,80 , and $18 \mu \mathrm{g} / \mathrm{mL} \mathrm{KBrO}_{3}$ for use in method A, method B, and method C, respectively.

(2) MetaCresol Purple Solution (80 and $200 \mu \mathrm{g} / \mathrm{mL}$ ). A $400 \mu \mathrm{g} / \mathrm{mL}$ stock solution was first prepared by dissolving $40 \mathrm{mg}$ of dye (Loba Chemie, Mumbai, India) in $2 \mathrm{~mL}$ of $0.1 \mathrm{~N}$ $\mathrm{NaOH}$ and diluted to volume with water in a $100 \mathrm{~mL}$ calibrated flask. The solution $(400 \mu \mathrm{g} / \mathrm{mL})$ was diluted further with water to get the working concentrations of $80 \mu \mathrm{g} / \mathrm{mL}$ and $200 \mu \mathrm{g} / \mathrm{mL}$ MCP solutions.

(3) Erioglaucine Solution $(300 \mu \mathrm{g} / \mathrm{mL})$. The solution was prepared by dissolving $30 \mathrm{mg}$ of dye (Loba Chemie, Mumbai, India) in water and diluting to the mark with water in a $100 \mathrm{~mL}$ calibrated flask.

(4) Hydrochloric Acid (5M and $1 M$ ). The solutions were prepared by appropriate dilution of concentrated hydrochloric acid (S. D. Fine Chem. Ltd., Mumbai, India. Sp. gr. 1.18) with water.

(5) Standard ATN Solution. Pharmaceutical grade atenolol (ATN) certified to be $99.89 \%$ pure was gifted by Cipla India Ltd., Mumbai, India, and was used as received without any further purification and analysis. A stock standard solution equivalent to $200 \mu \mathrm{g} / \mathrm{mL}$ ATN was prepared by dissolving accurately weighed $50 \mathrm{mg}$ of pure drug with water in a $250 \mathrm{~mL}$ calibrated flask. This stock solution was diluted appropriately with water to get the working concentrations of $40 \mu \mathrm{g} / \mathrm{mL}$ for use in methods A and C, and $80 \mu \mathrm{g} / \mathrm{mL}$ for use in method B.

\subsection{Assay Procedure}

2.3.1. Method A (Measuring MCP in Acid Medium). Different aliquots $(0.25-5.0 \mathrm{~mL})$ of standard ATN solution $(40 \mu \mathrm{g} / \mathrm{mL})$ were accurately transferred into a series of $10 \mathrm{~mL}$ calibrated flasks using microburette and the total volume was adjusted to $5.0 \mathrm{~mL}$ by adding requisite volume of water. To each flask, $2 \mathrm{~mL}$ of $5 \mathrm{M} \mathrm{HCl}$ was added followed by $1 \mathrm{~mL}$ of bromate-bromide mixture $\left(40 \mu \mathrm{g} / \mathrm{mL}\right.$ in $\left.\mathrm{KBrO}_{3}\right)$. The content was mixed well and the flasks were allowed to stand for $15 \mathrm{~min}$ with occasional shaking. Then, $1 \mathrm{~mL}$ of $80 \mu \mathrm{g} / \mathrm{mL}$ MCP was added to each flask, diluted to the mark with water, mixed well, and the absorbance of each solution was measured at $540 \mathrm{~nm}$ against a reagent blank after $5 \mathrm{~min}$.

2.3.2. Method B (Measuring Brominated Product of MCP). Varying aliquots $(0.25-5.0 \mathrm{~mL})$ of a standard solution $(80 \mu \mathrm{g} / \mathrm{mL}$ ATN $)$ were accurately measured into a series of $10 \mathrm{~mL}$ calibrated flasks and the total volume was brought to 
TABLE 1: Comparison of the proposed and the existing visible spectrophotometric methods.

\begin{tabular}{|c|c|c|c|c|c|c|c|c|}
\hline $\begin{array}{l}\text { Sl. } \\
\text { No. }\end{array}$ & Reagent/s used & Reagent used & $\begin{array}{l}\lambda_{\max } \\
(\mathrm{nm})\end{array}$ & $\begin{array}{l}\text { Linear range, } \\
\mu \mathrm{g} / \mathrm{mL} \text { and } \\
\varepsilon, \mathrm{L} / \mathrm{mol} \cdot \mathrm{cm} \\
\end{array}$ & $\begin{array}{l}\text { LOD, } \\
\mu \mathrm{g} / \mathrm{mL}\end{array}$ & $\begin{array}{l}\text { Reaction } \\
\text { time, min }\end{array}$ & Remarks & Reference \\
\hline (1) & $\begin{array}{l}\text { Hydroxylamine } \\
\text { hydrochloride- } \\
\text { iron } \\
\text { (III) }\end{array}$ & $\begin{array}{l}\text { Ferric hydroxamate } \\
\text { complex measured }\end{array}$ & 510 & $\begin{array}{l}50-800 \\
\left(\varepsilon=5.3 \times 10^{2}\right)\end{array}$ & NR & $20-30$ & $\begin{array}{l}\text { Less sensitive, } \\
\text { heating } \\
\text { required }\end{array}$ & {$[51]$} \\
\hline (2) & Chloranilic acid & $\begin{array}{l}\text { Charge transfer } \\
\text { complex measured }\end{array}$ & 534 & $25-250$ & NR & - & $\begin{array}{l}\text { Less sensitive, } \\
\text { use of organic } \\
\text { solvents }\end{array}$ & {$[52]$} \\
\hline (3) & Chloranilic acid & $\begin{array}{l}\text { Charge transfer } \\
\text { complex measured }\end{array}$ & 530 & $10-280$ & NA & NA & -do- & {$[53]$} \\
\hline (4) & $\begin{array}{l}\text { Acetaldehyde- } \\
\text { Chloranil }\end{array}$ & & 690 & NA & NA & NA & $\begin{array}{l}\text { Use of organic } \\
\text { solvents }\end{array}$ & {$[54]$} \\
\hline (5) & $\mathrm{NH}_{4} \mathrm{VO}_{3}$ & $\begin{array}{l}\text { Reaction rate } \\
\text { measured }\end{array}$ & 750 & NA & NA & NA & $\begin{array}{l}\text { Heating } \\
\text { required }\end{array}$ & {$[55]$} \\
\hline (6) & $\begin{array}{l}\text { 4-chloro-7- } \\
\text { nitrobenzo-2-oxa- } \\
\text { 1,3-diazole }\end{array}$ & $\begin{array}{l}\text { Coupling product } \\
\text { measured as a } \\
\text { function of time }\end{array}$ & 460 & $5-50$ & 1.3 & 30 & $\begin{array}{l}\text { Heating } \\
\text { required }\end{array}$ & {$[56]$} \\
\hline \multirow{4}{*}{ (7) } & \multirow{4}{*}{$\begin{array}{l}\text { Potassium } \\
\text { permanganate- in } \\
\text { alkaline medium }\end{array}$} & $\begin{array}{l}\text { Unreacted } \mathrm{KMnO}_{4} \\
\text { measured }\end{array}$ & 526 & & & $4 \mathrm{hrs}$ & \multirow{4}{*}{$\begin{array}{l}\text { Time- } \\
\text { consuming, } \\
\text { involve judicial } \\
\text { control of many } \\
\text { experimental } \\
\text { variables }\end{array}$} & \multirow[t]{4}{*}[57]{} \\
\hline & & $\begin{array}{l}\text { Rate-constant } \\
\text { method }\end{array}$ & & $6.66-10.65$ & & & & \\
\hline & & $\begin{array}{l}\text { Fixed-concentration } \\
\text { method }\end{array}$ & & $6.66-5.33$ & & & & \\
\hline & & Fixed-time method & & $6.66-7.99$ & & & & \\
\hline (8) & $\begin{array}{l}\text { Sodium } \\
\text { nitroprusside }\end{array}$ & $\begin{array}{l}\text { Complex of } \\
\text { ammonia and } \\
\text { nitroprusside } \\
\text { measured }\end{array}$ & 495 & $\begin{array}{l}0.5-30 \\
\left(\varepsilon=3.01 \times 10^{5}\right)\end{array}$ & 0.01 & 5 & $\begin{array}{l}\text { Heating } \\
\text { required }\end{array}$ & {$[58]$} \\
\hline (9) & $\begin{array}{l}\text { Chloramine-T- } \\
\text { metol-sulphanilic } \\
\text { acid }\end{array}$ & $\begin{array}{l}\text { Unreacted } \\
\text { chloramine-T } \\
\text { measured }\end{array}$ & 520 & $\begin{array}{l}2.5-25 \\
\left(\varepsilon=3.24 \times 10^{3}\right)\end{array}$ & 2.34 & 20 & Less sensitive & {$[59]$} \\
\hline \multirow{3}{*}{ (10) } & Chloramine-T: & & & & & & & \multirow{3}{*}[60]{} \\
\hline & (a) Metanil yellow & $\begin{array}{l}\text { Unreacted } \\
\text { chloramine-T } \\
\text { measured }\end{array}$ & 530 & $\begin{array}{l}1-12 \\
\left(\varepsilon=1.19 \times 10^{4}\right)\end{array}$ & 0.32 & 10 & & \\
\hline & $\begin{array}{l}\text { (b) Indigo } \\
\text { carmine }\end{array}$ & & 610 & $\begin{array}{l}2.5-20 \\
\left(\varepsilon=6.65 \times 10^{3}\right)\end{array}$ & 0.04 & 10 & & \\
\hline (11) & $\begin{array}{l}\text { Bromate-bromide } \\
\text { mixture- methyl } \\
\text { orange }\end{array}$ & $\begin{array}{l}\text { Unreacted bromine } \\
\text { measured }\end{array}$ & 520 & $\begin{array}{l}0.5-4.0 \\
\left(\varepsilon=4.13 \times 10^{4}\right)\end{array}$ & 0.07 & 15 & & {$[61]$} \\
\hline (12) & Phenol red & $\begin{array}{l}\text { The change in the } \\
\text { color of phenol red } \\
\text { measured }\end{array}$ & 430 & $\begin{array}{l}3.0-30 \\
\left(\varepsilon=3.47 \times 10^{3}\right)\end{array}$ & 4.61 & - & Less sensitive & {$[62]$} \\
\hline \multirow{3}{*}{ (13) } & $\begin{array}{l}\text { Bromate-bromide } \\
\text { mixture: } \\
\text { (a) MCP }\end{array}$ & $\begin{array}{l}\text { Unreacted MCP in } \\
\text { acid measured }\end{array}$ & 540 & $\begin{array}{l}1.0-20.0 \\
\left(\varepsilon=1.20 \times 10^{4}\right)\end{array}$ & 0.12 & 15 & \multirow{3}{*}{$\begin{array}{l}\text { Simple, } \\
\text { sensitive and no } \\
\text { heating step. No } \\
\text { use of organic } \\
\text { solvent. Use of } \\
\text { an eco-friendly } \\
\text { brominating } \\
\text { reagent. }\end{array}$} & \multirow[t]{3}{*}{$\begin{array}{l}\text { This } \\
\text { work }\end{array}$} \\
\hline & (b) MCP & $\begin{array}{l}\text { Bromo-derivative of } \\
\text { MCP measured }\end{array}$ & 445 & $\begin{array}{l}2.0-40.0 \\
\left(\varepsilon=4.51 \times 10^{3}\right)\end{array}$ & 0.56 & 10 & & \\
\hline & (c) EGC & $\begin{array}{l}\text { Unreacted EGC in } \\
\text { acid measured }\end{array}$ & 630 & $\begin{array}{l}1.0-8.0 \\
\left(\varepsilon=3.46 \times 10^{4}\right)\end{array}$ & 0.05 & 10 & & \\
\hline
\end{tabular}




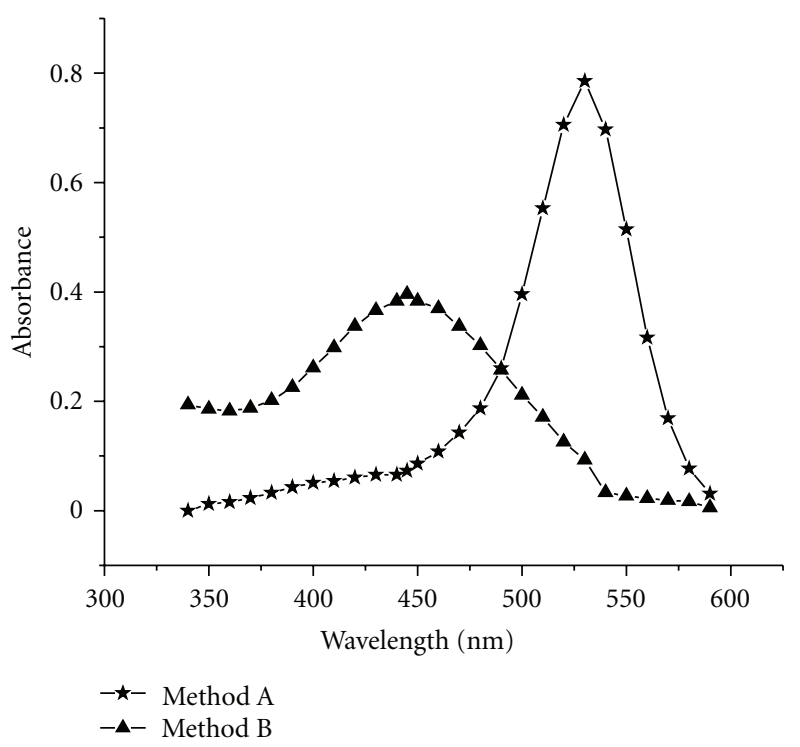

(a)

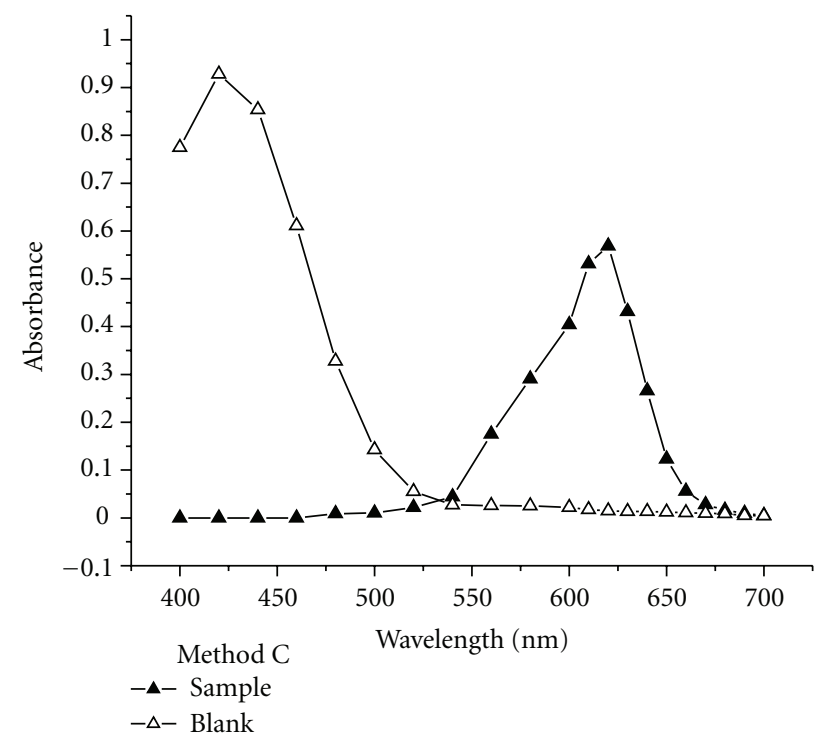

(b)

Figure 1: Method A: $1 \mathrm{~mL} 80 \mu \mathrm{g} / \mathrm{mL}$ MCP; $2 \mathrm{~mL} 5 \mathrm{M} \mathrm{HCl}$. Method B: Brominated product of MCP $(1 \mathrm{~mL} 40 \mu \mathrm{g} / \mathrm{mL}$ bromated-bromide mixture; $2 \mathrm{~mL} 5 \mathrm{M} \mathrm{HCl} ; 1 \mathrm{~mL} 80 \mu \mathrm{g} / \mathrm{mL}$ MCP). Method C: Sample: $1 \mathrm{~mL} 40 \mu \mathrm{g} / \mathrm{mL}$ ATN; $5 \mathrm{~mL} 1 \mathrm{M} \mathrm{HCl} ; 1 \mathrm{~mL} 18 \mu \mathrm{g} / \mathrm{mL}$ bromated-bromide mixture; $1 \mathrm{~mL} 300 \mu \mathrm{g} / \mathrm{mL}$ EG. Blank: $5 \mathrm{~mL} 1 \mathrm{M} \mathrm{HCl} ; 1 \mathrm{~mL} 18 \mu \mathrm{g} / \mathrm{mL}$ bromated-bromide mixture; $1 \mathrm{~mL} 300 \mu \mathrm{g} / \mathrm{mL}$ EG.

$5 \mathrm{~mL}$ by adding water. To each flask were added $2 \mathrm{~mL}$ of $5 \mathrm{M}$ $\mathrm{HCl}$ and $1 \mathrm{~mL}$ of $\mathrm{KBrO}_{3}-\mathrm{KBr}$ solution $\left(80 \mu \mathrm{g} / \mathrm{mL}\right.$, in $\left.\mathrm{KBrO}_{3}\right)$. The content of each flask was mixed well and kept aside for $10 \mathrm{~min}$ with occasional swirling. At last, $1 \mathrm{~mL}$ of $200 \mu \mathrm{g} / \mathrm{mL}$ MCP solution was added to each flask and diluted up to the mark with water. The absorbance of each solution was measured after $5 \mathrm{~min}$ at $445 \mathrm{~nm}$ against water.

2.3.3. Method C (Using EGC). Aliquots $(0.25-2.0 \mathrm{~mL})$ of a standard ATN $(40 \mu \mathrm{g} / \mathrm{mL})$ solution were accurately transferred into a series of $10 \mathrm{~mL}$ calibrated flasks and the total volume was adjusted to $2.0 \mathrm{~mL}$ with water. To each flask, $5 \mathrm{~mL}$ of $1 \mathrm{M} \mathrm{HCl}$ was added followed by $1.0 \mathrm{~mL}$ of bromatebromide mixture $\left(18 \mu \mathrm{g} / \mathrm{mL}\right.$, in $\left.\mathrm{KBrO}_{3}\right)$. The content was mixed and the flasks were let stand for 10 min with occasional shaking followed by addition of $1 \mathrm{~mL}$ of $300 \mu \mathrm{g} / \mathrm{mL}$ EGC to each flask. The solutions were diluted to the mark with water, mixed well, and the absorbance of each solution was measured at $630 \mathrm{~nm}$ after $5 \mathrm{~min}$ against a reagent blank.

2.3.4. Analysis of Commercial Tablets. Twenty tablets each containing 25,50, or $100 \mathrm{mg}$ of ATN were weighed accurately and pulverized. An amount of powdered tablet equivalent to $20 \mathrm{mg}$ of ATN was transferred into a $100 \mathrm{~mL}$ calibrated flask and $60 \mathrm{~mL}$ of water was added. The content was shaken thoroughly for about 15-20 min, diluted to the mark with water, mixed well, and filtered using a Whatman No. 42 filter paper. The first $10 \mathrm{~mL}$ portion of the filtrate was discarded and a suitable aliquot of the filtrate $(200 \mu \mathrm{g} / \mathrm{mL}$ ATN) was diluted to get the working concentrations of $40 \mu \mathrm{g} / \mathrm{mL}$ ATN for the assay by methods A and C, and $80 \mu \mathrm{g} / \mathrm{mL}$ ATN for method B.
2.3.5. Analysis of Placebo Blank. A placebo blank of the composition: talc $(45 \mathrm{mg})$, starch $(35 \mathrm{mg})$, acacia $(25 \mathrm{mg})$, methyl cellulose $(40 \mathrm{mg})$, sodium citrate $(25 \mathrm{mg})$, magnesium stearate $(35 \mathrm{mg})$, and sodium alginate $(30 \mathrm{mg})$ was made and its solution was prepared in $25 \mathrm{~mL}$ calibration flask as described under Section 2.3.4, and then subjected to analysis using the procedures described above.

2.3.6. Analysis of Synthetic Mixture. To the placebo blank of the composition described above, $20 \mathrm{mg}$ of ATN was added and homogenized, transferred to a $100 \mathrm{~mL}$ calibrated flask, and the solution was prepared as described under Section 2.3.4, and then subjected to analysis by the procedures described above. The analysis was used to study the interferences of excipients such as talc, starch, acacia, methyl cellulose, sodium citrate, magnesium stearate, and sodium alginate.

\section{Results and Discussion}

3.1. Absorption Spectra. The proposed methods are based on the determination of residual bromine generated in situ after the reaction between the drug and bromine is judged to be complete. The red-pink color of unreacted MCP in acid medium was absorbed maximally at $540 \mathrm{~nm}$ (method A). The residual bromine was then used to brominate MCP yielding yellow-colored bromo-derivative product with $\lambda_{\max }$ at $445 \mathrm{~nm}$ (method B). Similar to method A, the green color of unreacted EGC in acid medium peaked at $630 \mathrm{~nm}$ (method C). The absorption spectra of all methods are presented in Figure 1. 


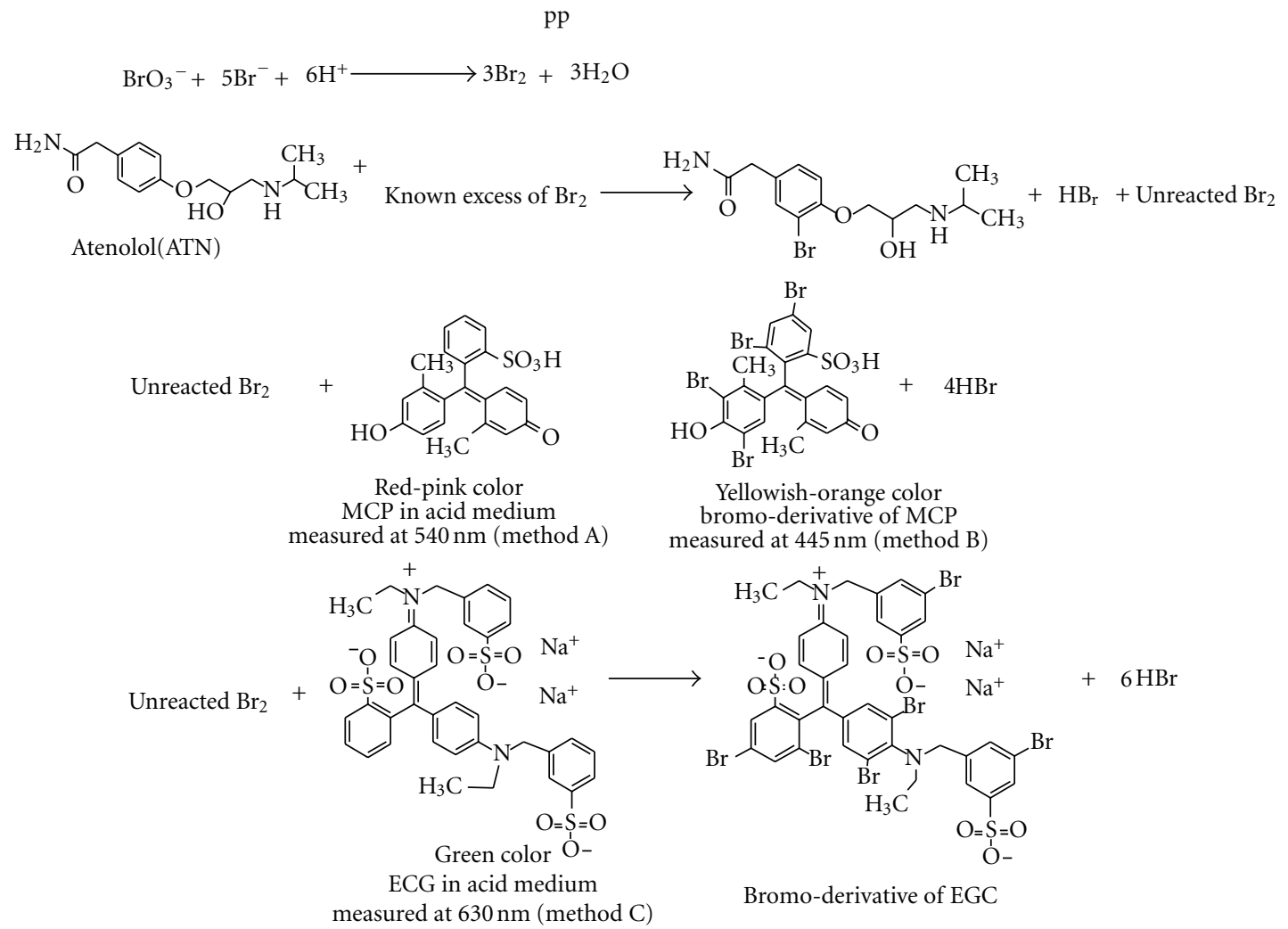

FIgURE 2: Tentative reaction scheme for the proposed methods.

3.2. Chemistry. Atenolol is reported to undergo bromination by bromine generated in situ by the action of the acid on the bromate-bromide mixture [61]. The solution of bromatebromide mixture in acid medium behaves as an equivalent solution of bromine and has been used for the assay of several pharmaceutical compounds [63-66]. The present investigation deals with three spectrophotometric methods for the assay of ATN using bromine generated in situ as eco-friendly brominating agent and avoiding the use of highly toxic and hazardous liquid bromine. The proposed methods are indirect and based on the bromination of ATN by the bromine followed by the determination of unreacted bromine by reacting with a fixed amount of either MCP or EGC and measuring the absorbance at the respective wavelengths. The reaction between ATN and bromine generated in situ uses electrophilic substitution reaction at one orthoposition to the alkoxy group on the benzene ring. The unreacted bromine was determined by its reaction with either MCP or EGC. The reaction of bromine with MCP involved two simultaneous processes, that is, decrease in the pink color of MCP in acid medium at $540 \mathrm{~nm}$ (method A) and increase in the yellowish-orange color at $445 \mathrm{~nm}$ (method B) due to the bromination of the dye. Similar to method A, unreacted bromine would react with EGC and the decrease in the absorbance of the green color of EGC in acid medium was measured at $630 \mathrm{~nm}$ (method C). The tentative reaction scheme is given and illustrated in Figure 2.
3.3. Basis of the Methods. ATN, when added in increasing concentrations to a fixed concentration of in situ bromine, consumed the latter and there occurred a concomitant fall in bromine concentration. When a fixed concentration of MCP was added to decreasing concentrations of bromine, a concomitant increase in the absorbance of MCP resulted at $540 \mathrm{~nm}$ and at the same time decrease in the absorbance resulted at $445 \mathrm{~nm}$. Similarly, when a fixed concentration of EGC was added to decreasing concentrations of bromine, a corresponding increase in the absorbance of EGC was observed at $630 \mathrm{~nm}$. These were observed as a proportional increase in the absorbance at $540 \mathrm{~nm}(\operatorname{method} A)$ or $630 \mathrm{~nm}$ (method C) and decrease at $445 \mathrm{~nm}$ (method B) with increasing the concentration of ATN.

\subsection{Optimization of Reaction Variables}

3.4.1. Effect of Reagent Concentration. Preliminary experiments were performed to fix the upper limits of the MCP and EGC that could produce a reasonably high absorbance, and these were found to be $80,200 \mu \mathrm{g} / \mathrm{mL}$ for MCP in methods $\mathrm{A}$ and $\mathrm{B}$, and $300 \mu \mathrm{g} / \mathrm{mL}$ for EGC in method C. Bromate concentrations of 4.0 and $1.8 \mu \mathrm{g} / \mathrm{mL}$ in the presence of excess bromide were found optimum to bleach the dye color in method A and method C, respectively, whereas $8.0 \mu \mathrm{g} / \mathrm{mL}$ $\mathrm{KBrO}_{3}$ produced a reasonable maximum absorbance at 


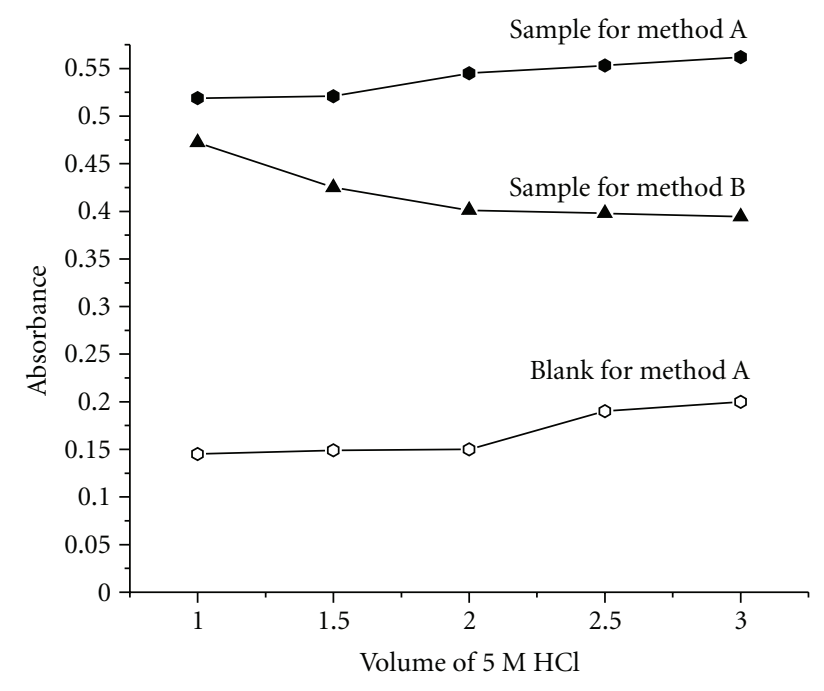

(a)

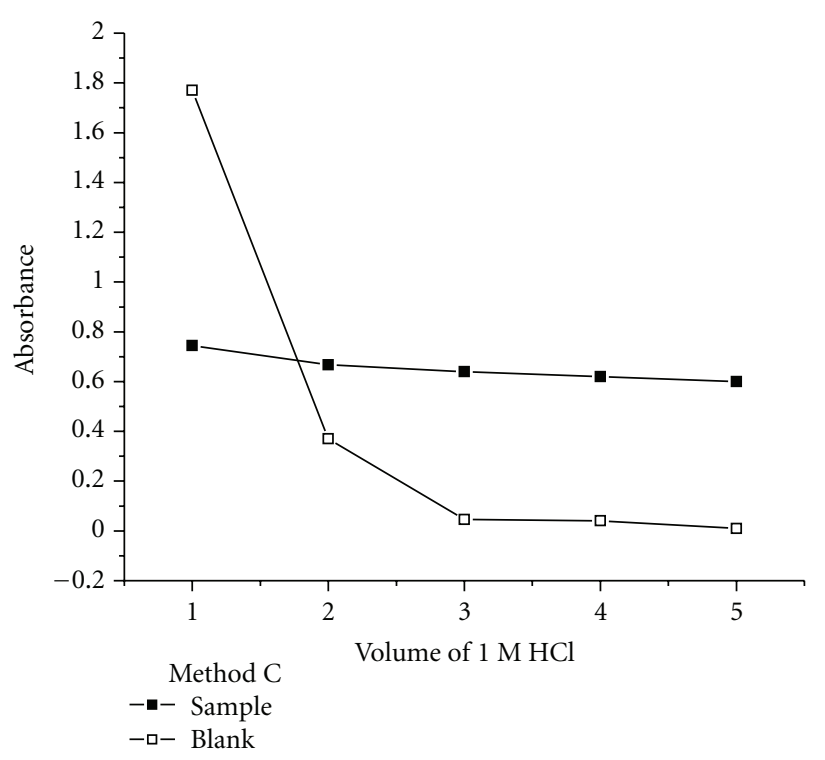

(b)

FIGURE 3: Effect of acid on the color development of the measured species for the proposed methods.

TABLE 2: Regression and analytical parameters.

\begin{tabular}{lccc}
\hline Parameter & Method A & Method B & Method C \\
\hline$\lambda_{\max }, \mathrm{nm}$ & 540 & 445 & 630 \\
Beer's law limits $(\mu \mathrm{g} / \mathrm{mL})$ & $1-20$ & $2-40$ & $1-8$ \\
Molar absorptivity $(\mathrm{L} / \mathrm{mol} \cdot \mathrm{cm})$ & $1.20 \times 10^{4}$ & $4.51 \times 10^{3}$ & 0.0591 \\
Sandell sensitivity* $\left(\mu \mathrm{g} / \mathrm{cm}^{2}\right)$ & 0.0223 & 0.56 & $0.46 \times 10^{4}$ \\
Limit of detection $(\mu \mathrm{g} / \mathrm{mL})$ & 0.12 & 1.69 & 0.077 \\
Limit of quantification $(\mu \mathrm{g} / \mathrm{mL})$ & 0.36 & 0.7755 \\
Regression equation, $Y^{* *}$ & & -0.0154 \\
Intercept & 0.0038 & -0.9973 \\
Slope & 0.0443 & 0.08471 & 0.14 \\
Correlation coefficient $(r)$ & 0.9996 & 0.00378 & 0.0217 \\
Standard deviation of intercept $\left(S_{a}\right)$ & 0.00664 & 0.1229 \\
Standard deviation of slope $\left(S_{b}\right)$ & 0.00059 & 0.01436 \\
S & & 0.00292 \\
\hline
\end{tabular}

${ }^{*}$ Limit of determination as the weight in $\mu \mathrm{g}$ per $\mathrm{ml}$ of solution, which corresponds to an absorbance of $A=0.001$ measured in a cuvette of cross-sectional area $1 \mathrm{~cm}^{2}$ and $\mathrm{l}=1 \mathrm{~cm} .{ }^{* *} Y=a+b X$, where $Y$ is the absorbance, $a$ is the intercept, $b$ is the slope, and $X$ is the concentration in $\mu \mathrm{g} / \mathrm{mL}$.

$445 \mathrm{~nm}$ in method B. Hence, different concentrations of ATN were reacted with $1.0 \mathrm{~mL}$ each of 40,80 , and $18 \mu \mathrm{g} / \mathrm{mL}$ bromate in methods $\mathrm{A}, \mathrm{B}$, and $\mathrm{C}$, respectively.

3.4.2. Effect of Reaction Medium. Hydrochloric acid was found to be an ideal medium for the two steps involved in all the three methods (Figure 3). In method A, the effect of (1.0$3.0 \mathrm{~mL}$ of $5 \mathrm{M} \mathrm{HCl}$ ) was studied and the results showed that $2.0 \mathrm{~mL}$ of $5 \mathrm{M} \mathrm{HCl}$ was optimum for the bromination reaction of the drug as well as the dye. Taking in to account the maximum absorbance of the measured species and the minimum absorbance of the blank, $2.0 \mathrm{~mL}$ of $5 \mathrm{M} \mathrm{HCl}$ was fixed. In method $\mathrm{B}, 2.0 \mathrm{~mL}$ of $5 \mathrm{M} \mathrm{HCl}$ was found optimum and any excess of the acid up to $3.0 \mathrm{~mL}$ would not affect the absorbance of the measured species. In method C, $5.0 \mathrm{~mL}$ of $1 \mathrm{M}$ $\mathrm{HCl}$ was found optimum to achieve maximum absorbance for the sample and minimum absorbance for the blank.
3.4.3. Reaction Time and Color Stability. The reaction time between ATN and the bromine generated in situ was found to be $15 \mathrm{~min}$ in method A and $10 \mathrm{~min}$ in both method B and method C. After completion the reaction between the drug and the bromine, the residual bromine would brominate the dyes and this bromination process was found to be complete in $5 \mathrm{~min}$ for all three methods. The absorbance of the measured species was constant up to 24 hours.

\subsection{Validation of the Proposed Methods}

3.5.1. Linearity. A linear relation is found between absorbance and concentration of ATN within Beer's law range given in Table 2. The calibration graphs are described by the equation:

$$
Y=a+b X
$$


TABLE 3: Evaluation of intraday and interday precision and accuracy.

\begin{tabular}{|c|c|c|c|c|c|c|c|}
\hline \multirow{2}{*}{ Method } & \multirow{2}{*}{$\operatorname{ATN}$ taken $(\mu \mathrm{g} / \mathrm{mL})$} & \multicolumn{3}{|c|}{ Intraday $(n=7)$} & \multicolumn{3}{|c|}{ Interday $(n=5)$} \\
\hline & & ATN found ${ }^{\mathrm{a}}(\mu \mathrm{g} / \mathrm{mL})$ & $\% \mathrm{RSD}^{\mathrm{b}}$ & $\% \mathrm{RE}^{\mathrm{c}}$ & ATN found $^{\mathrm{a}}(\mu \mathrm{g} / \mathrm{mL})$ & $\% \mathrm{RSD}^{\mathrm{b}}$ & $\% \mathrm{RE}^{\mathrm{c}}$ \\
\hline \multirow{3}{*}{ Method A } & 4.00 & 4.14 & 1.49 & 1.71 & 4.09 & 1.86 & 2.25 \\
\hline & 8.00 & 8.12 & 0.75 & 1.56 & 8.16 & 1.34 & 2.00 \\
\hline & 12.00 & 4.0 & 0.67 & 1.04 & 12.31 & 1.28 & 2.58 \\
\hline \multirow{3}{*}{ Method B } & 8.00 & 8.22 & 1.74 & 2.69 & 8.19 & 2.14 & 2.38 \\
\hline & 16.00 & 16.25 & 1.06 & 1.58 & 16.44 & 2.08 & 2.75 \\
\hline & 24.00 & 24.63 & 0.56 & 2.62 & 24.85 & 1.72 & 3.54 \\
\hline \multirow{3}{*}{ Method C } & 2.00 & 1.99 & 1.64 & 0.46 & 2.05 & 2.14 & 2.50 \\
\hline & 4.00 & 4.09 & 2.09 & 2.44 & 4.14 & 2.56 & 3.50 \\
\hline & 6.00 & 6.07 & 1.47 & 1.09 & 6.16 & 2.63 & 2.67 \\
\hline
\end{tabular}

${ }^{a}$ Mean value of five determinations; ${ }^{b}$ relative standard deviation (\%); ${ }^{c}$ relative error (\%).

TABLE 4: Robustness and ruggedness.

\begin{tabular}{|c|c|c|c|c|c|}
\hline \multirow{3}{*}{ Method } & \multirow{3}{*}{$\begin{array}{l}\text { ATN taken, } \\
\mu \mathrm{g} / \mathrm{mL}\end{array}$} & \multirow{2}{*}{\multicolumn{2}{|c|}{ Method robustness }} & \multicolumn{2}{|c|}{ Method ruggedness } \\
\hline & & & & \multirow[b]{2}{*}{$\begin{array}{l}\text { Interanalysts' } \\
\text { RSD, \% }(n=3)\end{array}$} & \multirow[b]{2}{*}{$\begin{array}{l}\text { Inter instruments' } \\
\mathrm{RSD}, \%(n=3)\end{array}$} \\
\hline & & $\begin{array}{l}\text { Volume of acid, } \mathrm{ml}^{\mathrm{a}} \\
\mathrm{RSD}, \%(n=3)\end{array}$ & $\begin{array}{l}\text { Reaction time }{ }^{\mathrm{b}} \\
\text { RSD, \% }(n=3)\end{array}$ & & \\
\hline \multirow{3}{*}{ A } & 4.00 & 1.26 & 1.46 & 1.34 & 2.64 \\
\hline & 8.00 & 0.72 & 1.72 & 0.85 & 3.18 \\
\hline & 12.00 & 0.64 & 1.28 & 1.03 & 3.03 \\
\hline \multirow{3}{*}{ B } & 8.00 & 0.85 & 1.39 & 1.42 & 2.86 \\
\hline & 16.00 & 0.52 & 0.92 & 1.17 & 2.47 \\
\hline & 24.00 & 1.18 & 1.15 & 1.33 & 3.26 \\
\hline \multirow{3}{*}{$\mathrm{C}$} & 2.00 & 1.26 & 1.26 & 1.06 & 3.42 \\
\hline & 4.00 & 0.96 & 1.39 & 0.88 & 2.78 \\
\hline & 6.00 & 1.08 & 0.76 & 1.24 & 2.37 \\
\hline
\end{tabular}

${ }^{\mathrm{a}}$ In methods $\mathrm{A}$ and $\mathrm{B}$, the volume of $5 \mathrm{M} \mathrm{HCl}$ was $1.8,2.0$, and $2.2 \mathrm{~mL}$ whereas in method $\mathrm{C}$, the volume of $1 \mathrm{M} \mathrm{HCl} \mathrm{was} 4.8,5.0$, and $5.2 \mathrm{~mL}{ }^{\mathrm{b}}$ The reaction time in methods A was 14, 15, and 16 min whereas in methods B and C, the same was 9, 10, and $11 \mathrm{~min}$.

TABLE 5: Results of analysis of tablets by the reference and proposed methods.

\begin{tabular}{|c|c|c|c|c|c|}
\hline \multirow{3}{*}{ Tablet Brand name } & \multirow{3}{*}{ Label claim mg/tablet } & \multicolumn{4}{|c|}{ Found (percent of label claim \pm SD) ${ }^{\mathrm{a}}$} \\
\hline & & \multirow{2}{*}{ Reference method } & \multicolumn{3}{|c|}{ Proposed methods } \\
\hline & & & Method A & Method B & Method C \\
\hline \multirow{3}{*}{ Atenex- $25^{\mathrm{b}}$} & \multirow{3}{*}{25} & \multirow{3}{*}{$100.3 \pm 0.58$} & $100.9 \pm 1.06$ & $99.65 \pm 0.96$ & $101.0 \pm 1.12$ \\
\hline & & & $t=1.11$ & $t=1.2$ & $t=1.28$ \\
\hline & & & $F=3.34$ & $F=2.74$ & $F=3.33$ \\
\hline \multirow{3}{*}{ Atekind- $50^{\mathrm{c}}$} & \multirow{3}{*}{50} & \multirow{3}{*}{$99.67 \pm 0.67$} & $101.0 \pm 1.09$ & $100.6 \pm 1.36$ & $99.81 \pm 1.42$ \\
\hline & & & $t=2.32$ & $t=1.42$ & $t=0.20$ \\
\hline & & & $F=1.48$ & $F=4.12$ & $F=4.49$ \\
\hline \multirow{3}{*}{ Aten- $100^{d}$} & \multirow{3}{*}{100} & \multirow{3}{*}{$100.6 \pm 0.82$} & $100.6 \pm 1.11$ & $101.1 \pm 1.37$ & $99.72 \pm 1.69$ \\
\hline & & & $t=0.03$ & $t=0.69$ & $t=1.05$ \\
\hline & & & $F=1.83$ & $F=2.79$ & $F=4.25$ \\
\hline
\end{tabular}

${ }^{a}$ Mean value of five determinations. ${ }^{\text {b,d }}$ Marketed by Zydas Healthcare, East Sikkim, India, ${ }^{\mathrm{c}}$ Marketed by Mankind Pharma Ltd., New Delhi, India, Tabulated $t$-value at the $95 \%$ confidence level is 2.78 . Tabulated $F$-value at the $95 \%$ confidence level is 6.39 . 


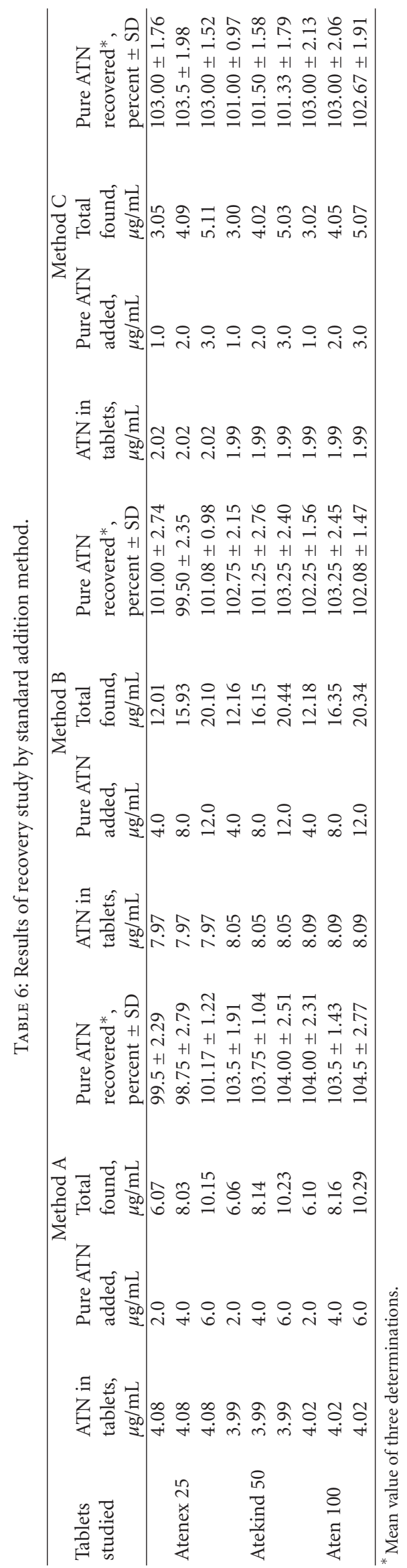


(where $Y=$ absorbance, $a=$ intercept, $b=$ slope and $X=$ concentration in $\mu \mathrm{g} / \mathrm{mL}$ ) obtained by the method of least squares. The apparent molar absorptivity $(\varepsilon)$, Sandell's sensitivity, limits of detection (LOD), and quantification (LOQ) are also given in the Table 2. Limits of detection (LOD) and quantification (LOQ) were calculated from the following equations [67]:

$$
\begin{aligned}
\mathrm{LOD} & =\frac{3.3 \times \sigma}{S}, \\
\mathrm{LOQ} & =\frac{10 \times \sigma}{S},
\end{aligned}
$$

where $\sigma$ is the standard deviation of " $n$ " reagent blank determinations and $S$ is the slope of the calibration curve.

3.5.2. Accuracy and Precision. In order to study the precision and accuracy of the proposed methods, three concentrations of pure ATN within the linearity range were analyzed, each determination being repeated seven times (intraday precision) in the same day and one time each for five days (interday precision). The percentage relative standard deviation (\%RSD) was $\leq 2.09 \%$ (intraday) and $\leq 2.63 \%$ (interday). In addition, the accuracy of the proposed method was measured by calculating the percentage relative error (\%RE), which was varied between $0.46 \%$ and $3.54 \%$. The results of this study indicate the high accuracy and precision of the proposed methods (Table 3 ).

3.5.3. Robustness and Ruggedness. To evaluate the robustness of the methods, two important experimental variables, namely, the amount of acid and reaction time, were slightly varied, and the capacity of the methods was found to remain unaffected by small deliberate variations. The results of this study are presented in Table 4 and indicate that the proposed methods are robust. Method ruggedness is expressed as $\%$ RSD of the same procedure applied by three analysts and using three different spectrophotometers by the same analyst. The interanalysts' and interinstruments' RSD values were $\leq 3.42 \%$ indicating ruggedness of the proposed methods. The results of this study are presented in Table 4.

3.5.4. Selectivity. In the present methods, a study of some potential interference was performed by selecting the excipients often used in pharmaceutical formulations or as possible coactive substances. Selectivity was evaluated by both placebo blank and synthetic mixture analyses. The placebo blank, consisting the composition as mentioned under Section 2.3.5 was prepared and analyzed as described under the recommended procedures. The resulting absorbance readings for the methods were the same as the reagent blank, inferring no interference from the placebo. The selectivity of the methods was further confirmed by carrying out recovery study from synthetic mixture. The percent recoveries of ATN were $102.1 \pm 1.35,101.9 \pm 1.18$, and $101.4 \pm 1.63$ for method A, method B, and method $\mathrm{C}$, respectively. This confirms the selectivity of the proposed methods in the presence of the commonly employed tablet excipients.
3.5.5. Application to Analysis of Pharmaceutical Samples. The proposed methods were successfully applied to the determination of ATN in three different brands of tablets, namely, Atenex-25, Atekind-50, and Aten-100. The results presented in Table 5 showed that there was a close agreement between the results obtained by the proposed methods and the label claim. The results were also compared with those of the reference method [3] statistically by a Student's $t$ - test for accuracy and variance ratio $F$-test for precision at 95\% confidence level. The reference method consisted of the measurement of the absorbance of the methanolic tablet solution at $275 \mathrm{~nm}$. The calculated $t$ - and $F$-values indicate that there is no significant difference between the proposed methods and the reference method with respect to accuracy and precision.

3.5.6. Recovery Studies. To study the reliability of the proposed method, a standard addition technique was followed. A fixed amount of drug from preanalyzed tablet powder was taken and pure drug at three different concentrations (50, 100 , and $150 \%$ of that in tablet powder) was added. The total concentration was found by the proposed methods. The determination with each concentration was repeated three times and the percent recovery of the added standard was calculated. Results of this study presented in Table 6 reveal that the accuracy of methods was unaffected by the various excipients present in the formulations.

\section{Conclusions}

Three sensitive spectrophotometric methods for the determination of ATN have been developed and validated based on the current ICH guidelines [67]. The present methods demonstrate that bromate-bromide mixture and metacresol purple or erioglaucine can be used for the quantitative determination of ATN in bulk drug as well as in tablets. The proposed methods have the advantages of utilization of bromine generated in situ as a green brominating reagent, free from critical experimental conditions, and complicated procedures such as heating or extraction step. The reagents used in the proposed methods are cheap, readily available, and the procedures do not involve any tedious sample preparation. These advantages encourage the application of the proposed methods in routine quality control analysis of ATN in pharmaceutical formulations.

\section{Acknowledgments}

The authors wish to acknowledge Cipla India Ltd., Mumbai, India, for providing the gift sample of atenolol. One of the authors K. N. Parashanth also wishes to thank the authorities of the University of Mysore for giving permission and facilities to carry out the research work.

\section{References}

[1] The Merck Index: An Encyclopedia of Chemicals, Drugs, and Biologicals, Merck \& Co., Whitehouse Station, NJ, USA, 11th edition, 1989. 
[2] R. N. Hegde, B. E. Kumara Swamy, B. S. Sherigara, and Nandibewoor S. T., "Electro-oxidation of atenolol at a glassy carbon electrode," International Journal of Electrochemical Science, vol. 3, no. 3, pp. 302-314, 2008.

[3] Indian Pharmacopoeia, Ministry of Health and Family Welfare, Government of India, New Delhi, India, 4th edition, 1996.

[4] British Pharmacopoeia, vol. I, Her Majesty's Stationary Office, London, UK, 1988.

[5] M. A. Gotardo, R. Sequinel, L. Pezza, and H. R. Pezza, "Determination of atenolol in pharmaceutical formulations by diffuse reflectance spectroscopy," Ecletica Quimica, vol. 33, no. 4, pp. 7-12, 2008.

[6] P. Modamio, C. F. Lastra, and E. L. Marino, "Error structure for the HPLC analysis for atenolol, metoprolol and propranolol: a useful weighting method in parameter estimation," Journal of Pharmaceutical and Biomedical Analysis, vol. 17, no. 3, pp. 507-513, 1998.

[7] S. S. Zarapkar, S. S. Kolte, and S. H. Rane, "High performance liquid chromatographic determination of amlodipine and atenolol, simultaneously from pharmaceutical preparation," Indian Drugs, vol. 34, no. 6, pp. 350-353, 1997.

[8] S. V. Erram and H. P. Tipnis, "Simultaneous determination of atenolol and nifedipine in solid dosage forms by RP [reversedphase] HPLC," Indian Drugs, vol. 29, no. 10, pp. 436-438, 1992.

[9] R. Jain and C. L. Jain, "Simultaneous microquantification of nifedipine and atenolol in multicomponent dosage forms using high performance liquid chromatography," Microchemical Journal, vol. 44, no. 2, pp. 187-192, 1991.

[10] D. Radulovic, L. J. Zivanovic, and G. Velimirovic, "High-performance liquid-chromatographic determination of atenolol in tablets," Analytical Letters, vol. 24, no. 10, pp. 1813-1823, 1991.

[11] R. T. Sane, V. R. Bhate, V. G. Nayak, and K. D. Ladge, "Simultaneous determination of atenolol, hydrochlorthiazide and amiloride hydrochloride frome marketed preparation by reversedphase high performance liquid chromatography," Indian Drugs, vol. 28, no. 7, pp. 322-325, 1991.

[12] Z. Pawlak and B. J. Clark, "The assay and resolution of the beta-blocker atenolol from its related impurities in a tablet pharmaceutical dosage form," Journal of Pharmaceutical and Biomedical Analysis, vol. 10, no. 5, pp. 329-334, 1992.

[13] L. Gong, "High-performance liquid-chromatographic determination of atenolol in compound tablets," Yaowu Fenxi Zazhi, vol. 9, pp. 175-176, 1989.

[14] S. I. Sa'sa, I. M. Jalal, and H. S. Khalil, "Determination of atenolol combinations with hydrochlorothiazide and chlorthalidone in tablet formulations by reverse-phase HPLC," Journal of Liquid Chromatography and Related Technologies, vol. 11, no. 8, pp. 1673-1696, 1988.

[15] R. Ficarra, P. Ficarra, A. Tommasini, M. L. Calabro, and C. Guarniera-Fenech, "HPLC determination of atenolol and chlorthalidone present together in pharmaceutical preparations," Farmaco-Edizione Pratica, vol. 40, no. 9, pp. 307-312, 1985.

[16] I. Rapado-Martinez, M. C. Garcia-Alvarez-Coque, and R. M. Villanueva-Camanas, "Liquid chromatographic procedure for the evaluation of $\beta$-blockers in pharmaceuticals using hybrid micellar mobile phases," Journal of Chromatography A, vol. 765, no. 2, pp. 221-231, 1997.

[17] M. I. R. M. Santoro, H. S. Cho, and E. R. M. Kedor-Hackmann, "Enantiomeric separation and quantitative determination of atenolol in tablets by chiral high-performance liquid chromatography," Drug Development and Industrial Pharmacy, vol. 26, no. 10, pp. 1107-1110, 2000.
[18] R. Ceresole, M. A. Moyano, M. T. Pizzorno, and A. I. Segall, "Validated reversed-phase HPLC method for the determination of atenolol in the presence of its major degradation product," Journal of Liquid Chromatography and Related Technologies, vol. 29, no. 20, pp. 3009-3019, 2006.

[19] L. Bing, D. F. Hu, and F. Liu, "HPLC determination of atenolol and nifedipine in compound atenolol tablets," Yaowu Fenxi Zazhi, vol. 24, no. 5, pp. 485-486, 2004.

[20] A. K. Singh, E. R. M. Kedor-Hackmann, and M. I. R. M. Santoro, "Development and validation of a chiral liquid chromatographic method for the determination of atenolol and metoprolol enantiomers in tablet preparations," Journal of AOAC International, vol. 84, no. 6, pp. 1724-1729, 2001.

[21] R. Bhushan and S. Tanwar, "Reversed-phase high-performance liquid chromatographic enantioresolution of six $\beta$-blockers using dinitrophenyl-L-Pro-N-hydroxysuccinimide ester, N-succinimidyl-(S)-2-(6-methoxynaphth-2-yl) propionate and twelve variants of Sanger's reagent as chiral derivatizing reagents," Biomedical Chromatography, vol. 23, no. 12, pp. 1291-1299, 2009.

[22] R. K. Barman, M. A. U. Islam, M. Ahmed et al., "Simultaneous high-performance liquid chromatographic determination of atenolol and amlodipine in pharmaceutical-dosage form," Pakistan Journal of Pharmaceutical Sciences, vol. 20, no. 4, pp. 274-279, 2007.

[23] A. Holbrook, A. M. Krstulovic, J. H. Miller, and J. Rysaluk, "Limitation of impurities in atenolol by liquid chromatography," Pharmeuropa, vol. 3, no. 3, pp. 218-225, 1991.

[24] R. Mehvar, "Stereospecific liquid chromatographic analysis of racemic adrenergic drugs utilizing precolumn derivatization with (-)menthyl chloroformate," Journal of Chromatography B, vol. 493, no. 2, pp. 402-408, 1989.

[25] P. P. Vazquez, M. M. Galera, A. S. Guirado, and M. M. P. Vazquez, "Determination of five beta-blockers in wastewaters by coupled-column liquid chromatography and fluorescence detection," Analytica Chimica Acta, vol. 666, no. 1-2, pp. 3844, 2010.

[26] S. El Deeb, "Evaluation of a vancomycin-based LC column in enantiomeric separation of atenolol: method development, repeatability study and enantiomeric impurity determination," Chromatographia, vol. 71, no. 9-10, pp. 783-787, 2010.

[27] A. P. Argekar and S. G. Powar, "Simultaneous determination of atenolol and amlodipine in tablets by high-performance thin-layer chromatography," Journal of Pharmaceutical and Biomedical Analysis, vol. 21, no. 6, pp. 1137-1142, 2000.

[28] A. P. Argekar and J. G. Sawant, "Simultaneous determination of atenolol and nitrendipine in pharmaceutical dosage forms by HPTLC," Journal of Liquid Chromatography and Related Technologies, vol. 22, no. 10, pp. 1571-1578, 1999.

[29] D. D. Rao, N. V. Satyanarayana, S. S. Sait, Y. R. Reddy, and K. Mukkanti, "Simultaneous determination of losartan potassium, atenolol and hydrochlorothiazide in pharmaceutical preparations by stability-indicating UPLC," Chromatographia, vol. 70, no. 3-4, pp. 647-651, 2009.

[30] G. S. Sadana and A. B. Ghogare, "Quantitative gas liquid chromatographic determination of atenolol in bulk drug and pharmaceutical preparations," Indian Drugs, vol. 28, no. 3, pp. 142-145, 1990.

[31] G. R. Rao, A. B. Avadhanulu, R. Giridhar, A. R. R. Pantulu, and C. K. Kokate, "Estimation of atenolol and nifedipine in single and combined dosage forms by GLC," Eastern Pharmacist, vol. 33, no. 386, pp. 113-115, 1990. 
[32] R. Ghanem, M. A. Bello, M. Callejon, and A. Guirafim, "Determination of beta-blocker drugs in pharmaceutical preparations by non-suppressed ion chromatography," Journal of Pharmaceutical and Biomedical Analysis, vol. 15, no. 3, pp. 383 $388,1996$.

[33] H. C. Zhao, N. H. Yan, and J. X. Guo, "Rapid determination of atenolol in tablets by flow-injection fluorimetry," Fenxi Shiyanshi, vol. 13, no. 5, pp. 36-38, 1994.

[34] M. Gajewska, G. Glass, and J. Kostelecki, "Spectrofluorimetric determination of propranolol and atenolol," Acta Poloniae Pharmaceutica, vol. 49, no. 3, pp. 1-4, 1992.

[35] G. Pyramides, J. W. Robinson, and S. W. Zito, "The combined use of DSC and TGA for the thermal analysis of atenolol tablets," Journal of Pharmaceutical and Biomedical Analysis, vol. 13, no. 2, pp. 103-110, 1995.

[36] K. A. Azzam, A. A. Elbashir, M. A. Elbashir, B. Saad, and S. A. Hamid, "Simultaneous determination of atenolol and chlorthalidone in pharmaceutical preparations by capillary-zone electrophoresis," Analytical Letters, vol. 42, no. 10, pp. 14581470, 2009.

[37] A. Shafaati and B. J. Clark, "Development and validation of a capillary zone electrophoretic method for the determination of atenolol in presence of its related substances in bulk and tablet dosage form," Journal of Pharmaceutical and Biomedical Analysis, vol. 14, no. 11, pp. 1547-1554, 1996.

[38] X. W. Zhou, J. Q. Lv, and Z. R. Zeng, "Determination of atenolol by capillary electrophoresis electrogenerated chemiluminescence," Fenxi Kexue Xuebao, vol. 23, no. 1, pp. 30-32, 2007.

[39] R. N. Goyal and S. P. Singh, "Voltammetric determination of atenolol at C60-modified glassy carbon electrodes," Talanta, vol. 69, no. 4, pp. 932-937, 2006.

[40] M. Shamsipur, F. Jalali, and S. Haghgoo, "Preparation of an atenolol ion-selective electrode and its application to pharmaceutical analysis," Analytical Letters, vol. 38, no. 3, pp. 401410, 2005.

[41] M. A. El Ries, "Indirect atomic absorption spectrometric (AAS) determination of atenolol," Analytical Letters, vol. 28, no. 9, pp. 1629-1639, 1995.

[42] C. V. N. Prasad, C. Parihar, K. Sunil, and P. Parimoo, "Simultaneous determination of amiloride $\mathrm{HCl}$, hydrochlorothiazide and atenolol in combined formulations by derivative spectroscopy," Journal of Pharmaceutical and Biomedical Analysis, vol. 17, no. 4-5, pp. 877-884, 1998.

[43] C. V. N. Prasad, C. Parihar, T. R. Chowdhary, S. Purohit, and P. Parimoo, "Simultaneous determination of atenololamlodipine and haloperidol-trihexyphenidyl in combined tablet preparations by derivative spectroscopy," Pharmacy and Pharmacology Communications, vol. 4, no. 7, pp. 325-330, 1998.

[44] D. Bonazzi, R. Gotti, V. Andrisano, and V. Cavrini, "Derivative UV spectrophotometric determination of atenolol and metoprolol in single-and multi-component pharmaceutical dosage forms," Farmaco, vol. 51, no. 11, pp. 733-738, 1996.

[45] S. Singh and R. Jain, "Simultaneous spectrophotometric determination of atenolol and amlodipine besylate from dosage forms," Indian Drugs, vol. 34, no. 11, pp. 678-679, 1997.

[46] S. Wang, "Determination of atenolol in tablets by spectrophotometry," Yaowu Fenxi Zazhi, vol. 10, no. 2, pp. 110-111, 1990.

[47] J. Huang and J. Jin, "Spectrophotometric determination of atenolol," Zhongguo Yiyao Gongye Zazhi, vol. 20, no. 1, pp. 1920, 1989.

[48] D. Satyanarayana, K. Kannan, and R. Manavalan, "Artificial neural network calibration models for simultaneous spectro- photometric determination of atenolol and losartan potassium in tablets," Chemia Analityczna, vol. 51, no. 5, pp. 771784, 2006.

[49] W. Wehner, "Determination of atenolol and chlortalidone during dissolution of tablets with UV multicomponent analysis," Die Pharmazie, vol. 55, no. 7, pp. 543-544, 2000.

[50] M. C. F. Ferraro, P. M. Castellano, and T. S. Kaufman, "Chemometrics-assisted simultaneous determination of atenolol and chlorthalidone in synthetic binary mixtures and pharmaceutical dosage forms," Analytical and Bioanalytical Chemistry, vol. 377, no. 7-8, pp. 1159-1164, 2003.

[51] Y. K. Agrawal, K. Raman, S. Rajpu., and S. K. Menon, "Spectrophotometric determination of atenolol via hydroxamic acid formation," Analytical Letters, vol. 25, no. 8, pp. 1503-1510, 1992.

[52] S. P. Agarwal, V. Singhal, and A. Prakash, "Spectrophotometric determination of atenolol and timolol dosage forms via charge-transfer complexation," Indian Journal of Pharmaceutical Sciences, vol. 60, no. 1, pp. 53-55, 1998.

[53] L. L. Yu, J. C. Liu, and H. K. Li, "Spectrophotometry determination of atenolol in tablets based on charge transfer complex of atenolol with chloranilic acid," Yaowu Fenxi Zazhi, vol. 30, no. 3, pp. 538-540, 2010.

[54] M. A. Korany, M. H. Abdel-Hay, S. M. Galal, and M. A. Elsayed, "Colorimetric determination of some $\beta$-adrenergic blocking drugs in tablets," Journal de Pharmacie de Belgique, vol. 40, no. 3, pp. 178-184, 1985.

[55] S. M. Sultan, "Kinetic methods for the determination of anenolol in pharmaceutical preparations," Acta Pharmaceutica Hungarica, vol. 62, no. 6, pp. 311-317, 1992.

[56] S. M. Al-Ghannam and F. Belal, "Kinetic spectrophotometric determination of atenolol in dosage forms," Journal of AOAC International, vol. 85, no. 4, pp. 817-823, 2002.

[57] G. C. Hiremath, R. M. Mulla, and S. T. Nandibewoor, "Kinetic methods of determination of atenolol in pure compound and in pharmaceutical formulations," Chemia Analityczna, vol. 50, no. 2, pp. 449-455, 2005.

[58] N. Bashir, S. W. H. Shah, M. Bangesh, and R. Riazullah, "A novel spectrophotometric determination of atenolol using sodium nitroprusside," Journal of Scientific and Industrial Research, vol. 70, no. 1, pp. 51-54, 2011.

[59] K. Basavaiah, U. Chandrashekar, and P. Nagegowda, "Determination of atenolol by spectrophotometry based on charge transfer complex formation reaction," Acta Ciencia Indica Chemistry, vol. 30, no. 1, pp. 75-79, 2004.

[60] K. Basavaiah, U. Chandrashekar, and P. Nagegowda, "Sensitive determination of atenolol in tablets using chloramine-T and two dyes," Indian Journal of Chemical Technology, vol. 11, no. 6, pp. 769-776, 2004.

[61] K. Basavaiah, U. Chandrashekar, and P. Nagegowda, "Titrimetric, spectrophotometric and kinetic methods for the assay of atenolol using bromate-bromide and methyl orange," Journal of the Serbian Chemical Society, vol. 71, no. 5, pp. 553$563,2006$.

[62] K. Basavaiah, U. Chandrashekar, B. C. Somashekar, and V. Ramakrishna, "Development and validation of neutralization reaction based on analytical methods for the assay of atenolol in pharmaceuticals," Proceedings of the National Academy of Sciences of India A, vol. 75, no. 4, pp. 233-238, 2005.

[63] K. Basavaiah, "Application of bromate-bromide mixture and methyl orange in the titrimetric, spectrophotometric and kinetic assay methods for cyproheptadine in pharmaceuticals," Indian Journal of Chemical Technology, vol. 13, no. 4, pp. 360366, 2006 
[64] A. M. El-Didamony and E. A. H. Erfan, "Utilization of oxidation reactions for the spectrophotometric determination of captopril using brominating agents," Spectrochimica Acta Part A, vol. 75, no. 3, pp. 1138-1145, 2010.

[65] K. Basavaiah and U. R. Anilkumar, "Sensitive spectrophotometric methods for quantitative determination of gatifloxacin in pharmaceutical formulations using bromate-bromide, thiocyanate and tiron as reagents," Journal of the Mexican Chemical Society, vol. 51, no. 2, pp. 106-112, 2007.

[66] K. Basavaiah and K. Tharpa, "Investigation and optimisation of the use of spectrophotometry for the assay of simvastatin with in situ bromine and three dyes as reagents," Journal of the Mexican Chemical Society, vol. 52, no. 3, pp. 193-200, 2008.

[67] ICH, International Conference on Harmonization of Technical Requirements for Registration of Pharmaceuticals for Human Use, 2005. 


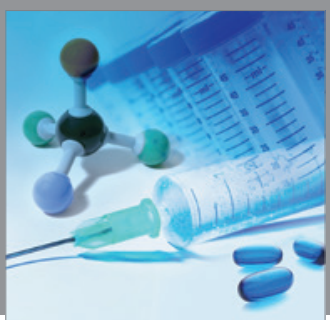

International Journal of

Medicinal Chemistry

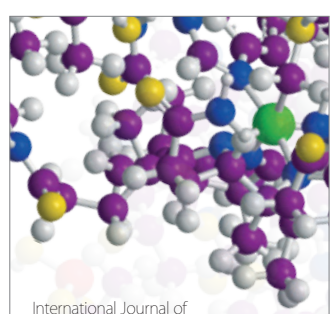

Carbohydrate Chemistry

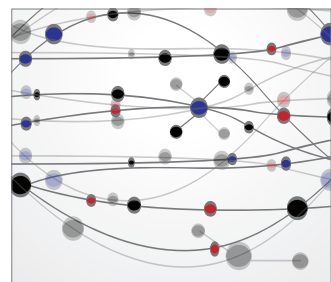

The Scientific World Journal
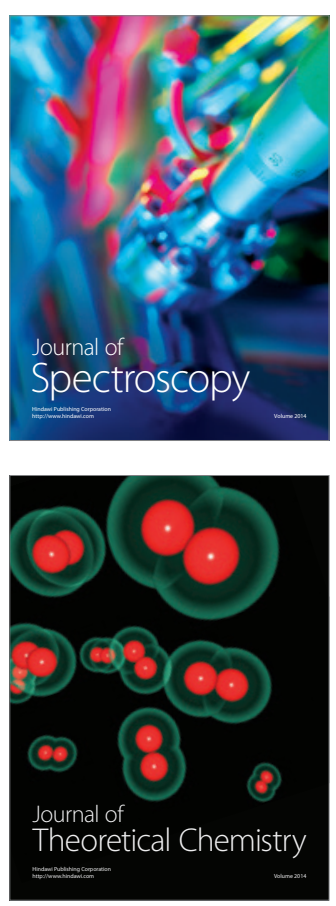
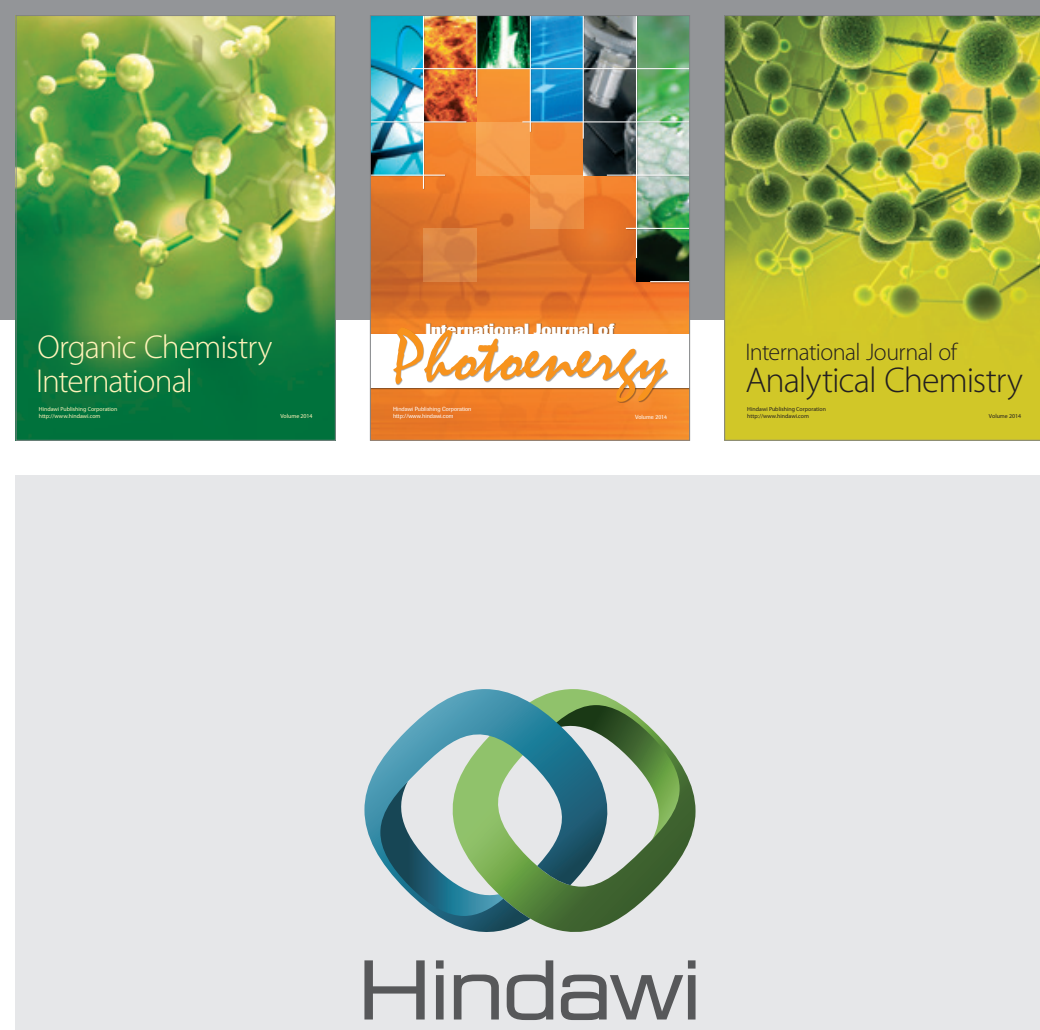

Submit your manuscripts at

http://www.hindawi.com
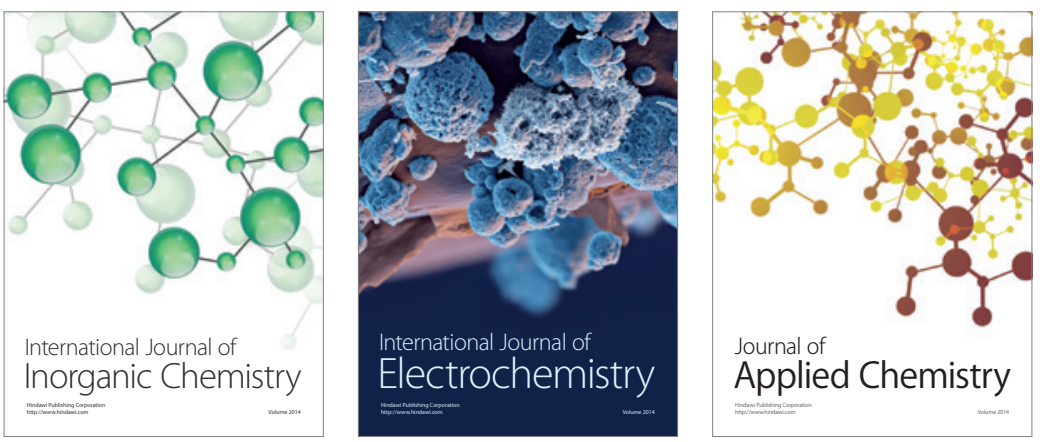

Journal of

Applied Chemistry
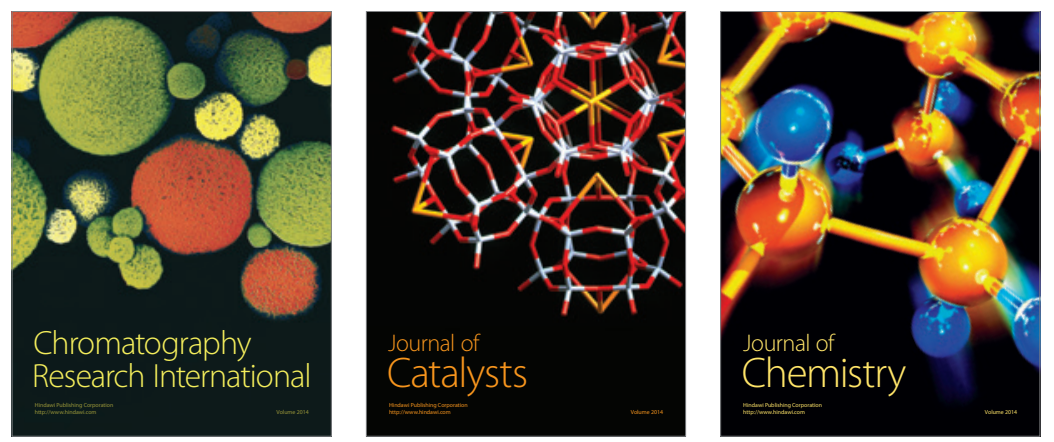
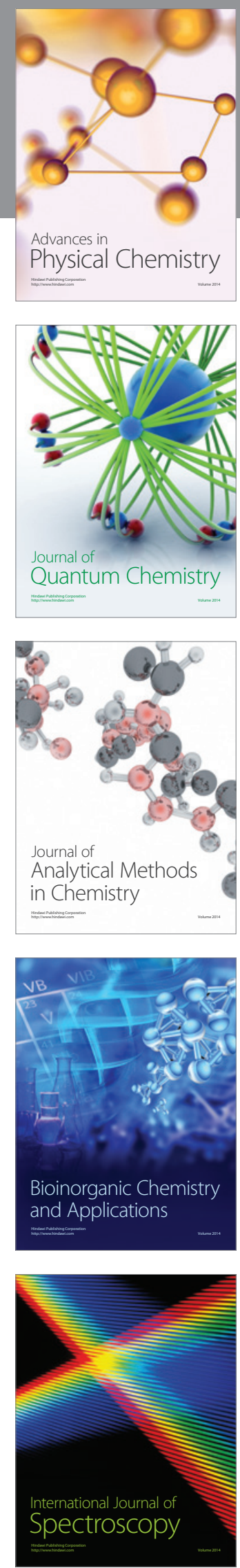